\title{
Examining the Long Run Relationship between the U.S. Money Supply (M2) and the Canadian Stock Market
}

\author{
Errefat Hamoud Thabet ${ }^{1}$ \\ ${ }^{1}$ International Centre for Education in Islamic Finance, Kuala Lumpur, Malaysia \\ Correspondence: Errefat Hamoud Thabet, INCEIF, Kuala Lumpur 59100, Malaysia. E-mail: \\ Errefat@hotmail.com \\ Received: June 23, 2014 \\ Accepted: July 9, 2014 \\ Online Published: August 25, 2014 \\ doi:10.5539/ijef.v6n10p180 \\ URL: http://dx.doi.org/10.5539/ijef.v6n10p180
}

\begin{abstract}
This paper investigates the possible impact of changes in the US Money Supply (M2) levels on the Canadian stock market using the S\&P/TSX Composite index as a proxy. The techniques employed are the error correction and variance decompositions techniques including 'long-run structural modelling (LRSM)' (Pesaran \& Shin, 2002), which has addressed the major shortcomings of the conventional cointegrating estimates by imposing exactly identifying and overidentifying restrictions on the cointegrating vector. The CUSUM and CUSUMSQ tests have been applied to test the stability of the coefficients. To the best of our knowledge, no research on this issue has been done using techniques that incorporate LRSM. Our findings indicate that shocks to the US money supply M2 have a significant cross-country positive impact on the prices of the S\&P/TSX composite index, and that there is a long-run relationship between these two variables. Both the error-correction model and the variance decomposition analysis applied in this paper tend to indicate that the US Money Supply M2 variable leads the S\&P/TSX composite index. These findings are of a significant importance to Canadian investors and portfolio managers on one hand as shocks to the US Money Supply (M2) are most likely to impact their portfolio investment; and to Canadian policy makers on the other hand as they can monitor the changes in the US Money Supply (M2) and adopt appropriate policies accordingly in order to absorb the spillover of the US monetary policy and help their stock market return to long-term equilibrium.
\end{abstract}

Keywords: money supply, stock market, monetary policy, time series, LRSM

\section{Introduction}

Economics literature has long showed that macroeconomic shocks heavily influence stock markets. There has been intensive research in the area of financial economics in the past two decades to determine the causal dynamics of stock prices and returns with other macroeconomic variables. However, issues regarding cross-country causal dynamics in regards to stock markets remain largely unresolved. The purpose of this study is to determine the long run relationship between US Money Supply (M2) and the Canadian stock market.

The correlation between Money supply (M2) and stock prices has been more or less recognized by Sprinkel (1964), Homa and Jaffee (1971), Keran (1971), Sorensen (1982), and most recently Maskay (2007). Furthermore, there have been several attempts to investigate the causality from Money Supply (M2) to stock prices within a single economy such as those done by Azlan and Azuddin (1998), Wong, Khan and Du (2005), and Pilinkus (2009). However, the causality of such a correlation in a cross-country dimension remains inconclusive.

Equity is widely used by fund managers as well as general investors to form their portfolios. Therefore, understanding the impact a monetary policy has on the stock market is very crucial, particularly in cointegrated markets where the possibility of gaining abnormal profits in the long term through diversifying investment portfolio is very limited (Masih, Al-Sahlawi \& De Mello, 2010). On the other hand, the United States of America and Canada have very strong economic relationship and interdependence as the US is considered as Canada's largest trading partner. Canada exports over 30\% of its GDP, equivalent to almost $80 \%$ of its exports, to the US which in return provides Canada with substantial investment capital through foreign investments (USTR, 2013). As such, the US has a high level of control over the Canadian economy. Consequently, changes in the US monetary policy is most likely to have an impact on the Canadian stock market. This, in turn, is of a significant importance to Canadian investors and portfolio managers as shocks to the US monetary policy are most likely to impact their portfolio investment. As such, investigating the possible impact of the US Money Supply (M2) on 
the Canadian stock market will most likely have a major contribution to predicting movements in the Canadian stock prices accordingly.

Maskay (2007) examined the relationship between a change in money supply and stock market prices. He used changes in money supply M2 as an independent variable and S\&P 500 as the dependent variable for stock prices in his Ordinary Lease Square (OLS) regression model. His findings indicated a positive relationship between a change in money supply and stock prices. He also examined the effect of unexpected changes in money supply M2 on S\&P 500 stock index and found that anticipated changes in money supply matter more than unanticipated change. His study shows that when the anticipated money supply changes by $\$ 48.4485$ billion on average, the S\&P 500 stock index increases by 22.91 points, but when the unanticipated positive money supply increases by $\$ 8.8746$ billion on average, the S\&P 500 index increases by only 4.2 points. His findings, somehow, contradict the Efficient Market Hypothesis (EMH) theory at the level of semi-strong form as proposed by (Fama, 1970).

The cross-country impact of the US monetary policy is significant to Canada. There are several studies which have documented several important macroeconomic linkages between the two countries. Anusiewicz \& Siklos (1998) performed a study on monetary linkages between Canada and the US and concluded that changes in the US monetary aggregates and short-term US interest rate produce corresponding changes in Canada's monetary aggregates, inflation rate, and short-term interest rates. Furthermore, Bailey (1989) examined the impact of US M1 growth on Canada's stock market and found that high/low US M1 growth results in lower/higher prices for Canadian stocks coupled with higher/lower Canadian short term interest rates. As such, changes in the US monetary policies are most likely to have a significant impact on Canadian Stock Markets.

This paper uses the S\&P/TSX Composite Index as a proxy of the Canadian Stock Market because it is an index where the largest Canadian companies are listed. Standard and Poor's (2013) identifies the S\&P/TSX Canadian Indices as follows:

"The S\&P/TSX Composite Index is the headline index and the principal broad market measure for the Canadian equity markets. It includes common stock and income trust units. Constituents of the S\&P/TSX Composite are also members of either the S\&P/TSX Equity indices (the S\&P/TSX Equity, the S\&P/TSX Equity 60, and the $\mathrm{S} \& \mathrm{P} / \mathrm{TSX}$ Equity Completion) or the suite of indices which include income trusts (the S\&P/TSX Income Trust, the S\&P/TSX Capped REIT, and the S\&P/TSX Capped Energy Trust), or both".

The scope employed in this paper is similar to that employed by Maskay (2007). However, this paper tends to further expand Maskay's work in the following aspects:

- In this paper, we use a time series technique to determine the causal long term relationship between US Money Supply M2 and the Canadian S\&P/TSX Stock index.

- This paper investigates the possible effect of changes in the US money supply levels on the Canadian S\&P/TSX composite index (cross-country effects) instead of the US monetary policy on the U.S S\&P 500 index.

- In this paper, the US interest rate variable has been excluded because Money Supply and interest rate have a great level of significant relationship. Therefore, including the interest rate in a cross-country analysis might increase multicollinearity exposure.

- In this paper, although our focus is on the long run relationship between US Money Supply (M2) and the Canadian S\&P/TSX Composite Index, these two variables, however, interact through some 'control' variables. Cornell (1983) indicated that stock markets are affected through inflation as a transmission channel. As such, we added the Canadian Consumer Price Index as a measure of inflation based on this theoretical foundation as a 'control' variable. Furthermore, given that in this paper we attempt to perform a cross-country analysis, we decided to include the USD/CAD exchange rate as another 'control' variable that is most likely to work as a transmission channel for the US Money Supply M2 into the Canadian stock market.

This study will start off by providing a theoretical background and literature review of the issue in section two, while section three will outline the methodology used in this paper. Empirical results and discussions are presented in section four. Finally, concluding remarks and policy implications will be presented in section five.

\section{Theoretical Framework}

There are competing theories on how the money supply affects the stock market prices. The most dominant theories are the ones developed by the Keynesian economists and the real activity theorists. Keynesian economists argue that there is a negative relationship between stock prices and money supply whereas real 
activity theorists argue that the relationship between the two variables is positive (Sellin, 2001). The Keynesian economists argue that changes in the money supply will affect the stock prices only if the change in the money supply alters expectations about future monetary policy. According to them, a positive money supply shock will lead people to anticipate tightening monetary policy in the future. They bid for funds in anticipation of tightening of money supply in the future, which will drive up the current rate of interest.

As the interest rate goes up, the discount rates go up as well and the present value of future earnings falls. Stock prices consequently decline. Furthermore, they argue that economic activities decline as a result of increase in interest rates, which further depresses stock prices (Sellin, 2001).

On the other hand, the real activity economists believe that changes in money supply, assuming accommodating monetary policy, provides information on money demand. In other words, they argue that increase in money supply means that money demand is increasing in anticipation of increase in economic activity. Higher economic activity implies higher expected profitability, which causes stock prices to rise. Hence, the real activity theorists argue that there is a positive relationship between money supply and stock prices (Sellin, 2001)

The theoretical framework is still inconclusive and there is a need for an empirical research to examine whether cross-country monetary policy changes have a significant causal relationship with stock markets.

\section{Methodology}

To assess the possible impact of US Money Supply M2 on the Canadian S\&P/TSX Composite index, we will employ a time series technique which is more appropriate for testing the temporal or lead-lag relationship between variables (Masih, Al-Elg, \& Madani, 2010). Furthermore, time series technique addresses the problem of the stationarity of the variables which the classical OLS regression technique cannot address.

Augmented Dickey-Fuller (ADF) test as well as Phillips-Perron (PP) test have been used to test the non-stationarity of the variables.

After examining the unit-root tests and the order of the VAR, we applied the Johansen cointegration test which uses two tests to determine the number of cointegration vectors, namely, the Maximum Eigenvalue test and the Trace test. The Maximum Eigenvalue statistic tests the null hypothesis of $\mathrm{r}$ cointegrating relations against the alternative of $r+1$ cointegrating relations. If cointegration has been detected between series, we know that there exists a long-run equilibrium relationship between them. However, evidence of cointegration does not provide information as to which variable is leading and which variable is lagging. To address this shortcoming, we applied the Vector error correction model VECM in order to evaluate the direction of Granger causality both in the short and long run. However, The VECM technique has a shortcoming in that while it determines the causal relationship among the variables, it does not indicate which variable is relatively more exogenous or endogenous. To address this shortcoming, we used the variance decomposition VDC technique (Masih, Al-Elg, \& Madani, 2010).

We then applied the impulse response function (IRF) which has been generated to explain the response to shocks amongst the variables. The IRF is a graphical method of exposing the relative exogeneity or endogeneity of a variable. Finally, we applied persistence profiles to estimate the speed at which the variables get back to equilibrium when there is a system-wide shock (Masih, Al-Elg, \& Madani, 2010).

The sample consists of 156 monthly data from January 2000 to December 2012 and was obtained from Datastream. The following variables are being used.

Table 1. Sample variables

\begin{tabular}{lccc}
\hline \multicolumn{1}{c}{ Variable } & Symbol & Logarithm form & Differenced form \\
\hline US Money Supply M2 & USM2 & LUSM2 & DUSM2 \\
Canadian S\&P/TSX Composite Index & TSX & LTSX & DTSX \\
Canadian Consumer Price Index & CPI & LCPI & DCPI \\
USD/CAD Exchange Rate & X & LX & DX \\
\hline
\end{tabular}

Variables were obtained in their level form, and then converted into the differenced form after being converted into $\log$ form for time series processing. 


\section{Empirical Results and Discussion}

We began our empirical testing by determining the stationarity of the variables used using the Augmented Dickey-Fuller (ADF) test. Tables 2 and 3 below summarize the ADF test results.

Table 2. Summarized ADF test results for testing variables in the level form

\begin{tabular}{|c|c|c|c|c|c|c|c|c|c|}
\hline Variable & Criteria & Test Statistic & Crit. Value & Implication & Variable & Criteria & Test Statistic & Crit. Value & Implication \\
\hline LUSM2 & AIC & -1.9878 & -3.4403 & Non-stationary & LCPI & AIC & -2.6963 & -3.4403 & Non-stationary \\
\hline LTSX & AIC & -2.5703 & -3.4403 & Non-stationary & LX & AIC & -3.1629 & -3.4403 & Non-stationary \\
\hline
\end{tabular}

Table 3. Summarized ADF test results for testing variables in the first differenced form

\begin{tabular}{llllllllll}
\hline Variable & Criteria & Test Statistic & Crit. Value & Implication & Variable & Criteria & Test Statistic & Crit. Value & Implication \\
\hline DUSM2 & AIC & -5.8011 & -2.8809 & Stationary & DCPI & AIC & -9.2672 & -2.8809 & Stationary \\
DTSX & AIC & -7.3846 & -2.8809 & Stationary & DX & AIC & -7.3513 & -2.8809 & Stationary \\
\hline
\end{tabular}

According to tables 2 and 3 above, the variables are non-stationary in their level form (test statistic $<$ critical value) and stationary in their difference (test statistic $>$ critical value). We selected the ADF order based on the highest value for AIC. Consequently, all the variables we are using for this study are I(1).

We then obtained results in table 4 which we used to determine the order of Vector autoregression VAR (i.e. the number of lags to be used).

Table 4. Determination of order of the VAR model

\begin{tabular}{lcc}
\hline & \multicolumn{3}{c}{ Criteria } \\
\cline { 2 - 3 } & AIC & SBC \\
Optimal order & 2 & 1 \\
\hline
\end{tabular}

The AIC and SBC computation results in table 4, each recommends a different optimal order of lags of 2 and 1 respectively. In the presence of such conflicting recommendations, we checked for serial correlation for each variable and obtained the results in table 5 which show that there is a serial correlation in one out of the four variables being used. As such, choosing a lower order based on SBC's recommendation might result in encountering the effects of serial correlation. On the other hand, adopting a higher order poses the risk of over-parameterization. However, with the relatively long time series (156 observations) we have, the risk of over-parameterization is minimized. As such, we decided to proceed with the higher VAR order of 2 as recommended by AIC.

Table 5. The results of serial correlation for each variable

\begin{tabular}{llllll}
\hline Variable & Chi-Sq $p$-value & Implication at $10 \%$ & Variable & Chi-Sq $p$-value & Implication at $10 \%$ \\
\hline DUSM2 & 0.211 & There is no serial correlation & DCPI & 0.011 & There is serial correlation \\
DSTX & 0.269 & There is no serial correlation & DX & 0.506 & There is no serial correlation \\
\hline
\end{tabular}

We then applied the standard Johansen cointegration test and obtained the results as shown in table 6.

Table 6. Johansen cointegration test

\begin{tabular}{lcccc}
\hline $\mathrm{H}_{0}$ & $\mathrm{H}_{1}$ & \multicolumn{1}{l}{ Statistic } & $95 \%$ Critical & $90 \%$ Critical \\
\hline \multicolumn{1}{l}{$\begin{array}{l}\text { 1. Maximal } \\
\mathrm{r}=0\end{array} \quad \mathrm{r}=1$} & 43.7656 & 31.7900 & \\
$\mathrm{r}<=1$ & $\mathrm{r}=2$ & 15.2721 & 25.4200 & 23.1300 \\
2. Trace of the Stochastic Matrix & & & \\
$\mathrm{r}=0$ & $\mathrm{r}>=1$ & 72.2381 & 63.0000 & 59.1600 \\
$\mathrm{r}<=1$ & $\mathrm{r}>=2$ & 28.4725 & 42.3400 & 39.3400 \\
\hline
\end{tabular}


Based on the Johansen conintegration test results, in the case of maximal eigenvalue and trace statistics, the null hypothesis is rejected at the 95 percent confidence level. As such, the results indicate that the variables have one cointegrating vector. SBC and HQC too, although not reported, tend to indicate that there is one cointegrating vector. Consequently, we conclude that there is one cointegrating vector.

The resultant evidence of a cointegrating relationship implies that there is a common force that brings the US Money Supply M2, USD/CAD exchange rate, Canadian Consumer Price Index CPI, and the Canadian Stock Index S\&P/TSX together in the long term. Being cointegrated, each variable contains information for the prediction of other variables. This cointegration has economic implications to investors in two main ways. The first is that portfolio diversification investors, particularly those diversifying between the US and Canadian markets, would learn that the two markets are cointegrated as the US Money Supply has an impact on both markets (Sirucek, 2011). Consequently, the possibility of gaining abnormal profits in the long term through diversifying investment portfolio is very limited (Masih, Al-Sahlawi \& De Mello, 2010). The second economic implication is for multinational firms operating between the two countries in regards to the coordination of their policies.

In order to make the coefficients of the cointegrating vector consistent with the theory, we then applied the LRSM. Since the number of the cointegrating relationship is one, we imposed an exact identifying restriction of 'unity' on the coefficient of TSX which is the variable of interest to our study and obtained the results in table 7 , panel 1 below. Based on the obtained results, we found that Canadian CPI (CPI) and USD/CAD Exchange Rate (X) were significant while US Money supply M2 (USM2) was found to be insignificant. Driven by our intuition that USM2 is significant, we decided to verify the significance of this variable by subjecting the estimate to over-identifying restrictions. To do this, we imposed an over-identifying restriction of 'zero' on the coefficient of US Money Supply M2 and obtained the results in table 7, panel 2. The results obtained tend to indicate that the null restriction of zero on US Money Supply M2 is rejected. This statistical evidence strengthens the theoretical underpinnings that Money Supply has an impact on stock markets. As such, based on this evidence as well as strong theoretical foundations, we proceed with panel 1 for the remainder of the analysis.

Table 7. The results of an over-identifying restriction of 'zero' on the coefficient of US Money Supply M2

\begin{tabular}{lcc}
\hline & Panel 1 & Panel 2 \\
\hline S\&P/TSX Composite Index (TSX) & 1.0000 & 1.0000 \\
& $\left(\right.$ NONE* $\left.^{*}\right)$ & $\left({ }^{*} \mathrm{NONE}^{*}\right)$ \\
US Money Supply M2 (USM2) & 6.6900 & 0.00 \\
& $(4.1944)$ & $\left(* \mathrm{NONE}^{*}\right)$ \\
Canadian CPI (CPI) & 48.1465 & 24.3970 \\
& $(23.8626)$ & $(9.8221)$ \\
USD/CAD Exchange rate (X) & 3.4089 & 3.9093 \\
& $(.85633)$ & $(.83461)$ \\
Trend & -.11177 & -.030516 \\
& $(.062252)$ & $(.013989)$ \\
Log Likelihood & 2054.4 & 2050.4 \\
Chi Square & NONE & $7.9343(.005)$ \\
\hline
\end{tabular}

Accordingly, we arrive at the following cointegrating equation (numbers in parentheses are standard deviations):

$$
\begin{gathered}
\mathrm{TSX}+6.69 \mathrm{USM} 2+48.15 \mathrm{CPI}+3.41 \mathrm{X} \rightarrow \mathrm{I}(0) \\
(4.1944) \quad(23.8628) \quad(.8563)
\end{gathered}
$$

The equation above does not give information on which variable is exogenous and which one is endogenous. The equation does not indicate the causal relationship. As such, in order to discern the endogeneity/exogeneity of the variables, we applied the vector error correction modelling technique as outlined in table 8 . 
Table 8. The vector error correction modelling technique

\begin{tabular}{lcccc}
\hline Variable & DUSM2 & DTSX & DCPI & DX \\
\hline DUSM2 & .17241 & 1.3582 & -.045108 & .50534 \\
& $(.081789)$ & $(1.0446)$ & $(.069735)$ & $(.41581)$ \\
DTSX & -.012359 & .14711 & .0050240 & -.22058 \\
& $(.0065565)$ & $(.083737)$ & $(.0055901)$ & $(.033333)$ \\
DCPI & -.22762 & .80350 & .23658 & .99740 \\
& $(.096552)$ & $(1.2331)$ & $(.082322)$ & $(.49086)$ \\
DX & .026236 & -.20832 & .0059988 & .098036 \\
& $(.015628)$ & $(.19960)$ & $(.013325)$ & $(.079453)$ \\
ECM(-1) & .0018377 & $-.050416^{*}$ & $-.0034554 *$ & -.0012226 \\
& $(.0011241)$ & $(.014356)$ & $(.0009584)$ & $(.0070996)$ \\
Chi-sq SC(12) & $16.4844(.170)$ & $16.4058(.173)$ & $24.4971(.017)$ & $11.0476(.525)$ \\
Chi-sq FF(1) & $4.2378(.040)$ & $2.3965(.122)$ & $1.8006(.180)$ & $.000005(.998)$ \\
Chi-sq N(2) & $.085803(.958)$ & $4.0167(.134)$ & $2.6500(.266)$ & $1.8818(.390)$ \\
Chi-sq Het(1) & $.0074840(.931)$ & $.82273(.364)$ & $.0031769(.955)$ & $1.7268(.981)$ \\
\hline
\end{tabular}

Note. *Implies significance of error-correction term (making S\&P/TSX Composite Index and Canadian CPI endogenous).

Looking at the significance or otherwise of the coefficient of the error correction term, we find that the US Money Supply M2 and USD/CAD Exchange rate variables are exogenous, whereas S\&P/TSX Composite Index and Canadian CPI variables are endogenous. This indicates that the US Money Supply M2 is the driver and the S\&P/TSX variable responds to the US Money Supply M2 variable. The error correction term in the S\&P/TSX equation is significant. It implies that the deviation of the variables has a significant feedback effect on the S\&P/TSX Composite index variable that bears the burden of short-run adjustment to bring about the long-term equilibrium (Masih, Al-Elg, \& Madani, 2010).

The economic implication of these results is that changes in the levels of US Money Supply (M2) impact the Canadian S\&P/TSX Composite index prices. The USM2 coefficient has a positive sign. This means that US Money Supply (M2) has a positive impact on the Canadian S\&P/TSX index. An increase in the levels of the US Money Supply (M2) will cause an increase the Canadian S\&P/TSX index prices. These findings are of interest to Canadian investors and policy makers. The US Money Supply (M2) variable, being an exogenous variable, would receive shocks and transmit the effects of those shocks to the S\&P/TSX Composite index prices. An investor who invests in S\&P/TSX Composite index would be interested to monitor movements in the US Money Supply M2, as shocks to that variable are likely to affect his/her investments. Likewise, news, events and developments that are likely to affect the US Money Supply M2 would be of interest to that investor. On the other hand, Canadian policy makers would be in a position to anticipate possible changes in the value of their equity as a result of changes in the levels of the US Money Supply M2 and will be able to adopt reactive policies accordingly.

Moreover, the VECM produces a statistic that may be of interest to investors and policy makers. The coefficient of $e_{t-1}$ represents the proportion of imbalance corrected in each period. For instance, in the case of the S\&P/TSX Composite index, the coefficient is 0.050416 . This implies the period in months it would take for the S\&P/TSX composite index to get back into equilibrium when there is a shock applied to it.

The results of the diagnostic statistics shown in table 8 above indicate that we have a Serial Correlation problem in the DCPI equation. The results also indicate that our data has a Functional Form problem with the DUSM2 equation. This could be attributed to the fact that other variables that influence US Money Supply (M2) were not included in the functional form. However, the focus of this paper is to examine the impact of US Money Supply (M2) on Canadian stock market, and not to identify the determinants of Money Supply.

The diagnostics results of the remaining equations of the error correction model (testing for the presence of autocorrelation, functional form, normality and heteroskedasticity) indicate that the equations are well-specified. Furthermore, we have also checked the stability of the coefficients using the CUSUM and CUSUM SQUARE tests and the results of the CUSUM and CUSUM SQUARE tests indicated that our coefficients are stable.

For variance decomposition, we applied Generalized Variance Decomposition VDC analysis. The matrix of VDCs with the forecast period of 12 months is shown in table 9. 
Table 9. Generalized variance decomposition (GVDC) analysis

\begin{tabular}{lcrrrr}
\hline \multicolumn{5}{c}{ Percentage of Forecast Variance Explained by Innovations in: } \\
& & $\Delta$ USM2 & $\Delta$ TSX & \multicolumn{1}{c}{$\Delta$ CPI } & \multicolumn{1}{c}{$\Delta$ X } \\
\hline Months & Relative variance in $\Delta$ USM2 & & & & \\
1 & & 73.66 & 6.28 & 2.36 & 17.70 \\
6 & & 68.09 & 10.96 & 1.67 & 19.27 \\
10 & & $\mathbf{6 5 . 6 9}$ & 11.51 & 1.20 & 21.59 \\
Months & Relative variance in $\Delta$ TSX & & & & \\
1 & & 1.96 & 76.78 & 0.30 & 20.96 \\
6 & & 1.31 & 62.16 & 11.09 & 25.43 \\
10 & & 2.57 & $\mathbf{5 9 . 5 1}$ & 12.31 & 25.61 \\
Months & Relative variance in $\Delta \mathrm{CPI}$ & & & & \\
1 & & 2.74 & 0.20 & 92.85 & 4.21 \\
6 & & 6.37 & 1.44 & 80.58 & 11.61 \\
10 & & 15.21 & 3.64 & $\mathbf{5 1 . 9 0}$ & 29.24 \\
Months & Relative variance in $\Delta \mathrm{X}$ & & & & \\
1 & & 10.28 & 27.74 & 1.00 & 60.98 \\
6 & & 10.35 & 35.64 & 0.74 & 53.27 \\
10 & & 9.61 & 39.52 & 0.68 & $\mathbf{5 0 . 1 9}$ \\
\hline
\end{tabular}

The above out-of-sample Generalized VDCs show the relative exogeneity and endogeneity of the variables. We can see that the relative exogeneity tend to change over time. Based on a 10-month horizon, the order of relative exogeneity double-strengthens our earlier findings in the VECM analysis in which USM2 was found exogenous. The ranking differ slightly from the ranking produced by the Orthogeneralized VDC analysis. It is, however, quite important to note that Orthogenalized VDCs depend largely on the particular ordering of the variables in the VAR. It also makes the assumption that when a given variable is shocked, other variables in the system are switched off. Conversely, Generalized VDCs do not depend on the order of the variables in the VAR, nor do they impose the restriction of switching off.

Given the impact US monetary policies have on the Canadian economy and relying on theoretical backgrounds that explain how monetary policies have spillover effects within integrated and interdependent economies such as those of the US and Canada (Fergusson, 2008), and relying on our earlier findings, we will rely on the Generalized VDC method and consider USM2 as the most exogenous variable that leads (rather than lags) the Canadian S\&P/TSX composite index. As such, we will rely on the following order of exogeneity as indicated by the Generalized VDC method:

Table 10. The order of exogeneity as indicated by the generalized VDC method

\begin{tabular}{ccc}
\hline & Relative Exogeneity & \\
Order & 6 months & 10 months \\
\hline 1 & CPI & USM2 \\
2 & USM2 & TSX \\
3 & TSX & CPI \\
4 & $\mathrm{X}$ & $\mathrm{X}$ \\
\hline
\end{tabular}

The economic implication of these findings (based on a 10-month horizon) is that investors and policy makers will have to watch closely the shocks in the US Money Supply M2 in order to predict a corresponding effect on their investments and equities within the Canadian S\&P/TSX Composite Index accordingly. Being the most exogenous variable, the US Money Supply (M2) will receive shocks and transmit the effects of those shocks to the Canadian S\&P/TSX Composite index. Consequently, stock prices within the S\&P/TSX will be impacted accordingly as a result of the changes in the US Money Supply levels.

The information which is presented in the VDCs can also be represented by Impulse Response Functions (IRFs) which present the graphical expositions of the shocks of a particular variable on all other variables. In other words, IRFs map the dynamic response path of all variables owing to a shock to a particular variable. Figures 1A-1D show the Generalized IRF of TSX when we shock other variables. 
Generalized Impulse Response(s) to one S.E. shock in the equation for LTSX

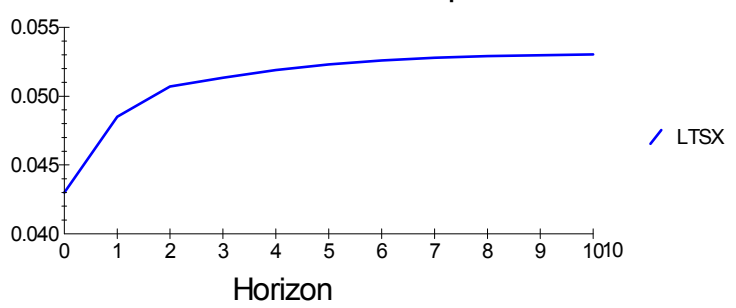

Figure 1a. Response of TSX when we shock TSX

Generalized Impulse Response(s) to one S.E. shock in the equation for LUSM2

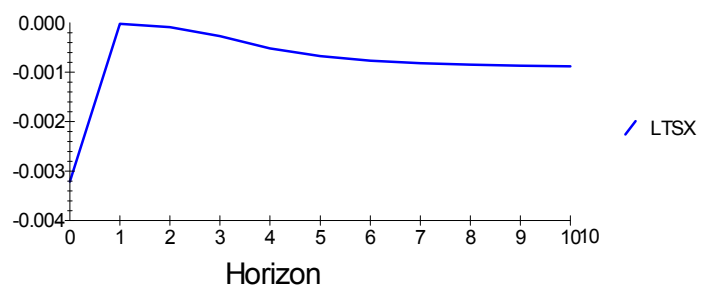

Figure 1b. Response of TSX when we shock USM2

Generalized Impulse Response(s) to one S.E. shock in the equation for LCPI

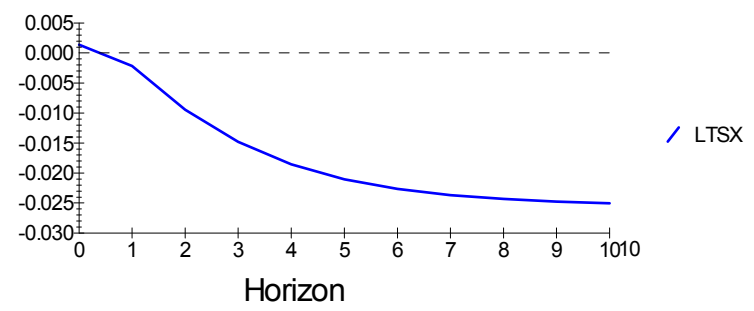

Figure 1c. Response of TSX when we shock CPI

Generalized Impulse Response(s) to one S.E. shock in the equation for $L X$

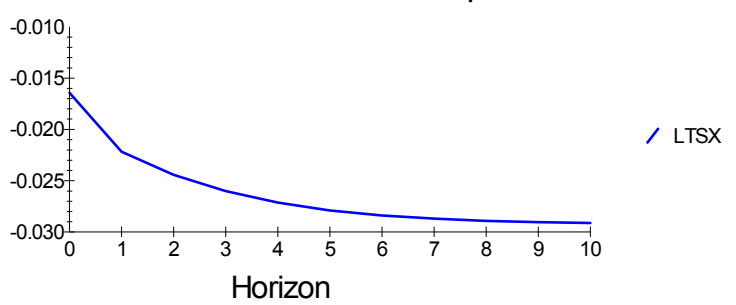

Figure 1d. Response of TSX when we shock X

Figures 1A-1D. Generalized IRFs

The IRFs presented above confirm our earlier findings that USM2 is the most exogenous among all variables. This strengthens our earlier findings in the VECM and VDC analyses where USM2 was found to lead the Canadian S\&P/TSX Composite index. As such, investors and policy makers can make use of such findings and anticipate corresponding effects to the S\&P/TSX when the US Money Supply (M2) is shocked as shocks to the US Money Supply (M2) are most likely to impact their investments and equities accordingly. 
The persistence profile test indicate that all variables in the cointegrating equation will need approximately 8 months to cointegrate again and return to long-run equilibrium.

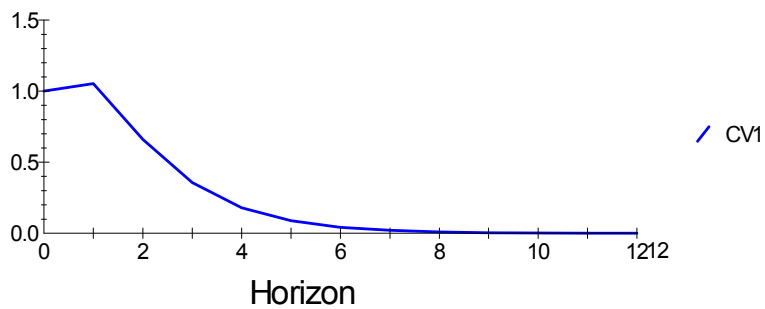

Figure 2. Persistence profile of the effect of a system-wide shock to CV'(s)

\section{Conclusion and Policy Implications}

The purpose of this paper is to examine the cross-country impact of the US Money Supply (M2) on the Canadian stock market. In order to test such a cross-country impact, we brought in two 'control' variables, namely, the Canadian Consumer Price Index and USD/CAD exchange rate which are most like to work as transmission channel for the cross-country impact of the US Money Supply (M2) on the Canadian S\&P/TSX composite index. We applied the time-series techniques including the VECM, generalized variance decompositions, and the long run structural modeling 'LRSM' (Pesaran \& Shin, 2002), which is an improvement on and an extension to the standard cointegrating techniques (Masih \& Algahtani, 2008). Our findings indicate that changes in the levels of US money supply M2 have a significant cross-country positive impact on the prices of the S\&P/TSX composite index. These findings support the findings of previous studies such as those of Sellin (2002) and Maskay (2007).

Moreover, our findings also indicate that there is a long-run relationship between the US money supply M2 and the prices of the S\&P/TSX composite index. The Johansen cointegration test applied in our study indicated the existence of a theoretical relationship between the US Money Supply M2 and the prices of the S\&P/TSX composite index and that they are in equilibrium in the long run.

Furthermore, our results indicate that the US Money Supply M2 has a causal impact on the prices of the S\&P/TSX composite index. Both the error-correction model and the Generalized variance decomposition analyses applied in this paper tend to indicate that the US Money Supply M2 variable is relatively more exogenous or leading and the Canadian S\&P/TSX composite index variable is relatively more endogenous or lagging.

Our findings are in line with the findings of Maskay (2007), who found a significant relationship between changes in money supply and stock prices, and those of Laeven and Tong (2010), who found that global stock prices responded strongly to changes in US interest rate policy.

The findings of this study have profound implications for Canadian investors and policy makers. Given the impact US Money Supply M2 has on Canadian stock market as established in this paper, Canadian investors and portfolio managers can monitor the changes in the levels of the US money supply M2 to predict the corresponding effect on their portfolio investments. Furthermore, given the impact of the US Money supply M2 on the US S\&P 500 stock market as established by Maskay (2007), portfolio diversification investors, particularly those diversifying between the US and Canadian stock markets would learn that the two markets are cointegrated. As such, the possibility of gaining abnormal profits in the long term through diversifying investment portfolio in these two markets is very limited. On the other hand, Canadian policy makers can monitor the changes in the US Money Supply M2 and adopt corrective policies in order to absorb the spillover of the US monetary policy and help their stock return to long-term equilibrium.

\section{References}

Anusiewicz, J., \& Siklos, P. L. (1998). The effects of Canadian and US M1 announcements on Canadian financial markets: The crow years. Journal of Economics and Business, 50, 49-65. http://dx.doi.org/10.1016/S0148-6195(97)00053-2

Asari, F. F. A. H., Baharuddin, N. S., Jusoh, N., Mohamad, Z., Shamsudin, N., \& Jusoff, K. (2011). A Vector Error Correction Model (VECM) Approach in Explaining the Relationship Between Interest Rate and Inflation Towards Exchange Rate Volatility in Malaysia. World Applied Sciences Journal, 12, 49-56. 
Akhtar, M. A., \& Hilton, R. S. (1984). Effects of Exchange Rate Uncertainty on U.S. and German Trade. Federal Reserve Bank of New York Quarterly Review, 9(1), 7-15.

Boudoukh, J., Richardson, M., \& Whitelaw, R. (1994). Industry Returns and the Fisher Effect. Journal of Finance, 49, 1595-1616. http://dx.doi.org/10.1111/j.1540-6261.1994.tb04774.x

Bernanke, B. S., \& Kuttner, K. N. (2005). What Explains the Stock Market's Reaction to Federal Reserve Policy? Journal of Finance, 60, 1221-1257. http://dx.doi.org/10.1111/j.1540-6261.2005.00760.x

Cornell, B. (1983). The Money Supply announcements puzzle: Review and interpretation. American Economic Review, 73, 664-657.

Cushman, D. O. (1983). US Bilateral Trade Flows and Exchange Rate Risk During the Floating Period. Journal of International Economics, 25, 317-330.

Fama, E. F. (1970). Efficient Capital Market: A Review of Theory and Empirical Work. Journal of Finance, 25. http://dx.doi.org/10.2307/2325486

Fergusson, I. (2008). United States-Canada Trade and Economic Relationship: Prospects and Challenges. Congressional Research, 4. Retrieved from http://www.nationalaglawcenter.org/assets/crs/RL33087.pdf

Homa, K. E., \& Jaffee, D. M. (1971). The Supply of Money and Common Stock Prices. The Journal of Finance, 26(5), 1045-1066. http://dx.doi.org/10.1111/j.1540-6261.1971.tb01747.x

Keran, M. (1971). Expectations, money and the stock market. Federal Reserve Bank of St. Louis Review, 53,1632.

Laeven, L., \& Tong, H. (2010). U.S Monetary Shocks and Global Stock Price.

Maskay, B. (2007). Analyzing the relationship between change in Money Supply and Stock Market Prices. Honors Projects, 35.

Masih, M., Al-Elg, A., \& Madani, H. (2010). Causality between financial development and economic growth: An application of the vector error correction and variance decomposition methods to Saudi Arabia. Applied Economics, 41(13), 1691-1699. http://dx.doi.org/10.1080/00036840701320233

Masih, M., \& Algahtani, I. (2008). Estimation of Long-run Demand for Money: An Application of Long-run Structural Modelling to Saudi Arabia. Economia Internazionale, 61(1), 81-99.

Masih, M., Al-Sahlawi, M. A., \& De Mello, L. (2010). What drives Carbon-Dioxide Emissions: Income or electricity generation? Evidence from Saudi Arabia. The Journal of Energy and Development, 33(2), 201213.

Pesaran, M. H., \& Shin, Y. (2002). Long-run structural modelling. Econometric Reviews, $21,49-87$. http://dx.doi.org/10.1081/ETC-120008724

Pilinkus, D. (2009). Stock market and macroeconomic variables: evidences from Lithuania. Economics and Management Journal, 14, 884-891.

Razi, A., Shafiq, A., Ali, S. A., \& Khan, H. (2012). Determinants of Exchange Rate and its Impact on Pakistani Economy. Global Journal of Management and Business Research, 12(16), 45-48.

Sellin, P. (2001). Monetary Policy and the Stock Market: Theory and Empirical Evidence. Journal of Economic Surveys, 15(4), 491-541. http://dx.doi.org/10.1111/1467-6419.00147

Sirucek, M. (2011). Impact of monetary policy on US stock market. Trends Economics and Management, V(9), 53-60.

Sorensen, E. H. (1982). Rational Expectations and the Impact of Money upon Stock Prices. Journal of Financial and Quantitative Analysis, 17(5), 649-662. http://dx.doi.org/10.2307/2330854

Sprinkel, B. (1964). Money and Stock Prices. Homewood, Illinois: Richard Irwin Inc.

Standard and Poor's. (2013). S\&P/TSX Canadian Indices. Retrieved from http://pdf.cyberpresse.ca/lapresse/dufour/SPTSX\%20Composite\%20Methodology.pdf

United States Trade Representative. (2013). US-Canada Trade Facts. Retrieved 10 April 2013, from http://www.ustr.gov/countries-regions/americas/canada

Wong, W. K., Khan, H., \& De, J. (2005). Money, Interest Rate, and Stock Prices: New Evidence from Singapore and the United States. U21Global Working Paper, No. 007/2005 


\section{Copyrights}

Copyright for this article is retained by the author(s), with first publication rights granted to the journal.

This is an open-access article distributed under the terms and conditions of the Creative Commons Attribution license (http://creativecommons.org/licenses/by/3.0/). 